\title{
Effects of community structure on the seagrass Thalassia testudinum
}

\author{
Craig D. Rose*, Clinton J. Dawes \\ Department of Biology, University of South Florida, Tampa, Florida 33620, USA
}

\begin{abstract}
The influence of community structure on the seagrass Thalassia testudinum was studied in 3 distinct communities: low and high density monocultures, and patches intermixed with Halodule wrightii, in Cockroach Bay, Tampa, Florida. T. testudinum shoot-specific leaf mass and growth were significantly higher in low density monocultures, and both variables were negatively correlated with short-shoot density. Intraspecific, competition-density effects in high-density seagrass beds may be responsible for the relatively lower shoot-specific leaf mass and growth rates, possibly due to the reduction of available light from dense leaf canopies. These observations are supported by significantly higher $T$ testudinum leaf $\mathrm{C}: \mathrm{N}$ and $\delta^{13} \mathrm{C}$ in low density monocultures, which suggests that high rates of growth are coupled with high $\mathrm{C}$ and $\mathrm{N}$ demands and reduced discrimination of $\mathrm{C}$. Lower $T$. testudinum shoot-specific leaf mass and growth in mixed species patches may be partially explained by interspecific competition with $H$. wrightii; however, the exact mechanisms by which these species interact were not discovered. Differences among communities in sediment $\mathrm{NH}_{4}{ }^{+}$and $\mathrm{PO}_{4}{ }^{3}$, and $T$ testudinum leaf $\mathrm{C}: \mathrm{N}: \mathrm{P}$ and $\delta^{15} \mathrm{~N}$ suggest that community structure in seagrass meadows plays an important role in sediment nutrient dynamics and, potentially, nutrient availability. However, low leaf $\mathrm{C}: \mathrm{N}$ and $\mathrm{C}: \mathrm{P}$ ratios suggest that nutrients are not limiting in this system. This study shows that intraspecific competition, and to a lesser degree, interspecific interactions with $H$. wrightii, are important determinants of $T$ testudinum productivity and, potentially, seagrass community structure in Cockroach Bay.
\end{abstract}

KEY WORDS: Seagrass - Thalassia testudinum - Heterogeneous · Community structure - Intraspecific competition - Nutrient availability

\section{INTRODUCTION}

The seagrasses Thalassia testudinum Banks ex König and Halodule wrightii Ascherson grow along the coastlines of the Caribbean and Gulf of Mexico in dense monocultures and mixed-species communities. Seagrass community structure (i.e. species diversity and abundance) may reflect fine scale variability in resource availability, abiotic factors, and/or bioturbation and meteorological disturbances. Localized environmental conditions have a direct effect on seagrass distribution patterns and growth (e.g. Zieman et al. 1989, Erftemeijer \& Herman 1994, van Tussenbroek 1995), and may indirectly promote and increase the importance of biotic interactions by reducing species'

\footnotetext{
- Present address: Department of Biological Sciences and Southeast Environment Research Program, Florida International University, Miami, Florida 33199, USA.

E-mail: crose01@fiu.edu
}

realized niches (en sensu Hutchinson 1957). Intra- and interspecific competition may be important processes that structure these communities.

Intraspecific competition in seagrasses has not been well studied (but see South 1983). A series of classical experiments in terrestrial plant literature (Kira et al. 1953, Koyama \& Kira 1956, Yoda et al. 1963) provide the foundation for the current understanding of intraspecific competition, which include competitiondensity effects, altered population structures, and the self-thinning rule. Determining the importance of intraspecific competition relative to interspecific competition in structuring plant communities has not been adequately tested due to poor experimental designs, problems associated with modeling monocultures, and the inconsistency of common intraspecific effects (e.g. self-thinning rule) in all communities (Antonovics \& Levin 1980, Firbank \& Watkinson 1990, Goldberg \& Barton 1992). On the other hand, interspecific competition has been widely investigated and reviewed (e.g. 
Connell 1983, Shoener 1983, Fowler 1986, McCreary 1991, Goldberg \& Barton 1992), although its importance and role in shaping plant communities is debated (Grace 1991, Turkington et al. 1993, Huisman 1994)

Competition in plant communities generally occurs via direct interference with neighbors (e.g. allelopathy), passive interactions by blocking access to resources, or indirectly by exploiting shared resource pools (Connell 1990). Direct interference competition, or allelopathy, has not been observed in seagrasses. However, de Villèle \& Verlaque (1995) observed diebacks of Posidonia oceanica (Linnaeus) Delile in the Mediterranean that were associated with the invasion of the green macroalga Caulerpa taxifolia (Vahl) C. Agardh. This alga produces toxic secondary metabolites that inhibit the growth and expansion of interspecific competitors (Lemée et al. 1993). In the absence of allelopathy, seagrasses may compete for sediment nutrients, light, or space (Williams 1987), by either physically blocking access to resource pools or by reducing the availability of limiting resources. Competition for available substrate occurs between crustose algae and species of the seagrass Phyllospadix in the intertidal zone along the northwest coast of the United States (Turner 1985, Stewart 1989). Further, seagrasses also compete with phytoplankton, epiphytes, and macroalgae for light and nutrients (Sand-Jensen \& Borum 1991, Duarte 1995). These interactions reduce seagrass distribution and growth in areas of high nutrient loading and reduced water quality (e.g. Silberstein et al. 1986, Tomasko \& Lapointe 1991, Neckles et al. 1993, 1994, Lapointe et al. 1994, Duarte 1995, Sturgis \& Murray 1997).

Competition between seagrasses has mostly been inferred from field observations where short shoot (SS) densities, leaf mass, and/or growth were lower in mixed communities relative to monocultures (Johnstone 1984, Kirkman 1985, Orth \& Moore 1987. Tomasko 1992). Nomme \& Harrison (1991) observed positive responses by Zostera japonica Ascherson \& Graebner when $Z$. marina $L$. was removed from mixed communities. Other field studies have focused on the mechanisms by which coexisting species interact, specifically by manipulating resource availability. Williams (1987) reported that Thalassia testudinum outcompeted Syringodium filiforme Kützing for both sediment nutrients and light, as $S$. filiforme SS density and biomass increased with higher resource availability. The resource-ratio hypothesis (Tilman 1982, 1988) was invoked to investigate the interactions between $T$ testudinum and Halodule wrightii in Florida Bay (Fourqurean et al. 1992b, 1995). In the latter study, monocultures of $T$. testudinum were eventually replaced by dense monocultures of $H$. wrightii after
8 yr of enrichment, reflecting the higher nutrient requirements of $H$. wrightii (Powell et al. 1991, Fourqurean et al. 1992b). During enrichment, H. wrightii was released from nutrient limitation and formed a dense canopy of aerial runners (en sensu) and SS in the water column above the seagrass bed. The authors suggested that light was subsequently reduced below the minimum for $T$. testudinum, though this was not further examined.

In the present study, we examined the importance of intra- and interspecific competition and resource availability in structuring a heterogeneous Thalassia testudinum and Halodule wrightii seagrass community. The focus of the present study is on the dominant $T$. testudinum, and thus $H$. wrightii will only be mentioned in reference to its effects on the distribution, growth, and physiological characteristics of $T$ testudinum. Our objectives were 2-fold: (1) to determine if intra-or interspecific interactions affected the abundance, leaf morphology, and growth of $T$. testudinum in a heterogeneous seagrass bed; and (2) to elucidate the mechanisms involved in structuring mixed $T$. testudinum and $H$. wrightii seagrass communities. The effects of intra- and interspecific competition were inferred from correlations of growth measures with density of intra- and interspecific neighbors (Harper 1977), and the spatial organization of $T$ testudinum and $H$. wrightii within mixed communities (Rejmánek \& Lepš 1996). T. testudinum shoot-specific leaf morphology, mass, growth, and stable $\mathrm{C}$ and $\mathrm{N}$ isotopic values were also measured to determine the effects of seagrass community structure on $T$. testudinum eco-physiological processes. Total sediment $\mathrm{NH}_{4}{ }^{+}$and $\mathrm{PO}_{4}{ }^{3-}$ and $T$. testudinum leaf tissue C:N:P ratios were measured to identify the relationships between nutrient availability and seagrass community structure.

\section{METHODS}

Site description. This study was conducted in Cockroach Bay $\left(27^{\circ} 40^{\prime} \mathrm{N}, 82^{\circ} 31^{\prime} \mathrm{W}\right.$ ), a shallow (ca 0.5 to $1.5 \mathrm{~m}$ ), mangrove-lined estuary located along the southeastern edge of Tampa Bay, Florida. The benthos in Cockroach Bay is dominated by large stands of Thalassia testudinum, intermixed with the seagrasses Halodule wrightii and Halophila engelmannii Ascherson, the macroalga Caulerpa prolifera (Forsskål) Lamouroux, bare patches, and boat propeller scars. The study site consists of a heterogeneous seagrass meadow (ca 1.5 ha) containing monocultures of $T$ testudinum and $H$. wrightii and patches where both species coexist. In August 1994, we identified 4 distinct seagrass communities based on species composition 
and abundance: low-density, monospecific stands of $T$. testudinum (LOW) with SS densities $<100 \mathrm{~m}^{-2}$; highdensity, monospecific stands of $T$. testudinum $(\mathrm{HIGH})$ with SS densities $>200 \mathrm{~m}^{-2}$; monospecific patches of $H$. wrightii (HW); and intermixed stands containing both species (MIX; also presented as T-MIX and H-MIX when referring to $T$. testudinum and $H$. wrightii individually in this community). SS densities ranged from 0 to $496 \mathrm{SS} \mathrm{m}^{-2}$ for $T$. testudinum and 0 to $2896 \mathrm{SS} \mathrm{m}^{-2}$ for $H$. wrightii throughout the study area (Rose 1996). Five sites of each community were randomly selected from a larger pool of potential sites. All sites were $10 \mathrm{~m}$ in diameter, but only the innermost $6 \mathrm{~m}$ of each site were sampled to insure differentiation between communities and to avoid edge effects. Additionally, the innermost $25 \mathrm{~cm}$ were excluded from the sampling area due to the placement of a $1.91 \mathrm{~cm}$ (diameter) PVC pipe inserted to mark the center of the sites. Because Cockroach Bay seagrasses are highly variable and exhibit strong seasonal responses (Dawes et al. 1997), we conducted the majority of our sampling during times of maximal (June 1995) and reduced (October 1994) seagrass productivity. All collections were conducted by snorkeling, and care was taken to prevent disturbing the study area by minimizing walking and use of anchors.

Seagrass density and spatial interspecific interactions. Thalassia testudinum SS densities in LOW, HIGH, and MIX, were calculated in October 1994 and June 1995 by sampling each site 20 times with a $0.0625 \mathrm{~m}^{-2}$ quadrat. Halodule wrightii SS were also counted in MIX. SS counts from both species in MIX were used to describe their spatial distribution patterns and measure their association strength. Spatial patterns were described using Lloyd's (L) index of patchiness (Pielou 1977, Rejmánek \& Lepš 1996), where

$$
L=1+\frac{\text { variance } /(\text { mean }-1)}{\text { mean }}
$$

and the mean and variance refer to the calculated mean and variance of the number of individual ramets (i.e. SS) in each quadrat for each species. When $L<1$, individuals are uniformly distributed; for $L \sim 1$, individuals approximate a random distribution; and if $L>1$, individuals exhibit a clumped distribution.

The strength of interspecific association between Thalassia testudinum and Halodule wrightii were measured via 2 methods. Pearson correlation coefficients (r) were calculated from the number of $T$. testudinum and $H$. wrightii SS (log transformed) present in each of the 100 quadrats sampled from all $5 \mathrm{MIX}$ communities. The 100 quadrats used to sample the 5 MIX communities were divided into 4 categories, based on the concurrent presence or absence of $T$. testudinum and $H$. wrightii. These values were used in an ordinary $2 \times 2$ contingency table to determine the $V$ coefficient (Pielou 1977), which is calculated as follows

$$
V=\frac{(a d-b c)}{|a d-b c|} \sqrt{\frac{\chi^{2}}{N}}
$$

where $a, b, c$, and $d$ are frequencies in the $2 \times 2$ table; $\chi^{2}$ is the chi-square statistic; and $N$ is the total number of sampling units. Absolute values of $V>0.20$ indicate a significant association between species for $N=100$ samples at a 0.05 significance level (Rejmánek \& Lepš 1996).

Thalassia testudinum leaf characteristics and growth. Leaf growth was measured in situ for Thalassia testudinum using a modification of Zieman's (1974) hole-punching technique in October 1994 and June 1995. Approximately 30 SS were marked with 2 holes by a 20 gauge syringe needle directly above the basal meristem, tagged with a plastic wire tag around the base of the SS, and harvested 8 to $14 \mathrm{~d}$ after they were marked. SS were stored on ice and processed within 48 h. Epiphytes were gently scraped from the blades, dried to a constant mass (ca $24 \mathrm{~h}$ at $60^{\circ} \mathrm{C}$ ), and weighed. The number of blades, 1 -sided leaf area, and total leaf mass were recorded. One-sided leaf area was measured on a Leaf Area Meter (CI-201, CID). Standing crop ( $\mathrm{g}$ dry weight $[\mathrm{d} w \mathrm{t}] \mathrm{m}^{-2}$ ) was estimated from the measures of leaf mass and SS density, and 3 measures of productivity were determined: shoot-specific

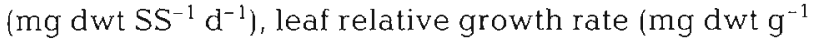
$\mathrm{d}^{-1}$ ), and areal ( $\left.\mathrm{g} d w t \mathrm{~m}^{-2} \mathrm{~d}^{-1}\right)$.

Sediment characteristics. In March 1995, a preliminary survey of sediment nutrient concentrations were conducted in LOW, HIGH, MIX, and HW communities. Five sediment cores ( $3 \mathrm{~cm}$ i.d., $10 \mathrm{~cm}$ length) were collected from 3 sites for each community; for a total of 15 cores community ${ }^{-1}$. Cores were immediately placed in plastic bags, transported back to the lab on ice, homogenized, and frozen $\left(-15^{\circ} \mathrm{C}\right)$ until analyzed. Visually identifiable plant material and detritus $(\geq 1 \mathrm{~cm})$ were removed from the cores during homogenization. Approximately $30 \mathrm{~g}$ of homogenized wet sediment were dried at $105^{\circ} \mathrm{C}$ to constant mass and ashed for $4 \mathrm{~h}$ at $500^{\circ} \mathrm{C}$ to determine total organic matter (TOM). Ammonium was extracted from wet subsamples (ca $5 \mathrm{~g}$ ) with $2 \mathrm{M} \mathrm{KCl}$ (Bremmer 1965) and measured colormetrically (Kempers \& Zweers 1986). Phosphate was extracted from wet subsamples (ca $5 \mathrm{~g}$ ) with $0.5 \mathrm{M}$ sodium bicarbonate $\left(\mathrm{Na}_{2} \mathrm{HCO}_{3}\right)$ and was also measured colormetrically (Olsen \& Sommers 1982). In June 1995, 5 sediment cores were collected (concurrently with the growth studies) from each site in LOW, HIGH, and MIX for a total of 25 cores community ${ }^{-1}$. Cores were similarly processed.

Thalassia testudinum elemental and isotopic composition. Five SS of Thalassia testudinum were col- 

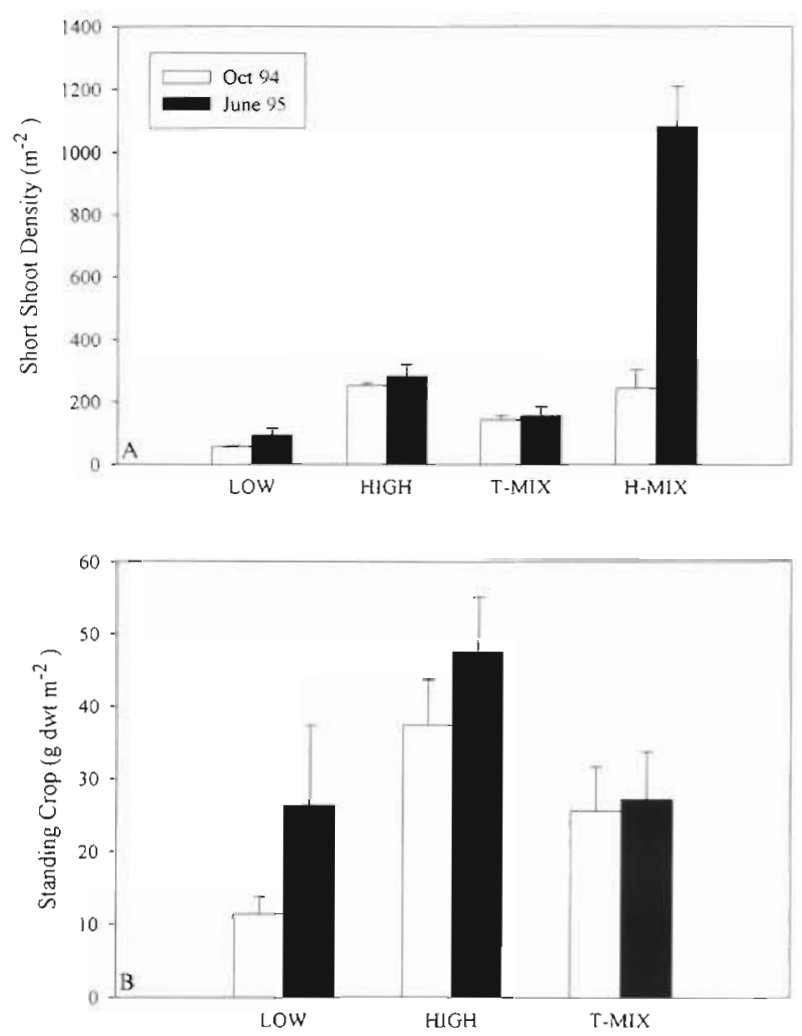

Fig. 1. Mean (+1 SD) seagrass (A) short shoot (SS) density and (B) standing crop of LOW, HIGH, and MIX communities sampled in October 1994 and June 1995. Note that data for both Thalassia testudinum (T-MIX) and Halodule wrightii ( $\mathrm{H}-\mathrm{MIX}$ ) in MIX communities are provided only for SS densities, and not standing crop

lected from all sites in June 1995. Blades were separated from the shoot, rinsed in freshwater, scraped clean of epiphytes, dried to a constant mass, and homogenized in a Wiley-Mill (screen no. 40). Carbon and nitrogen contents were determined using a Carlo Erba Model $1500 \mathrm{CHN}$ analyzer and phosphorus content was measured by dry oxidation-acid hydrolysis (Fourqurean et al. 1992a). Carbon, N, and P were determined from duplicate samples. The C:N, C:P, and $\mathrm{N}:$ P molar ratios were calculated on a mol:mol basis for pooled shoots from each site. Seagrass leaf $\delta^{13} \mathrm{C}$ and $\delta^{15} \mathrm{~N}$ were measured on a stable isotope mass spectrometer. Results are presented in standard delta $(\delta)$ notation.

Thalassia testudinum daily leaf nutrient demands. Three measures of daily leaf nutrient demands are reported for Thalassia testudinum: (1) on a per SS basis ( $\mathrm{mg}$ nutrient $\mathrm{SS}^{-1}$ ), (2) on a per mass basis (mg nutrient $\mathrm{g}^{-1}$ leaf), and (3) on an areal basis ( $\mathrm{mg}$ nutrient $\mathrm{m}^{-2}$ ). Calculations were based on means from each community for SS density, standing crop, leaf mass, leaf productivity, and leaf $\% \mathrm{~N}$ and \% P content measured in June 1995.
Data analysis. One-way ANOVA was used to test for differences among communities for sediment characteristics. Thalassia testudinum leaf tissue elemental ratios, and $T$. testudinum stable isotopic measurements. Differences in SS density, standing crop, leaf characteristics, and growth were tested among communities, sampling dates, and community $\times$ date interactions, using 2-way ANOVA. Pairwise multiple comparisons among communities were made with the Student-Newman-Keuls method. Correlations were conducted with the Pearson Product Moment Correlation. All data were tested for normality and homogeneity of variances, and were transformed if data were not normally distributed. Significance was determined a priori at a $95 \%$ probability level $(p \leq 0.05)$.

\section{RESULTS}

\section{Seagrass density and spatial interspecific interactions}

Differences among communities were determined in preliminary surveys of the study area and were consistent throughout the study. Thalassia testudinum SS densities were significantly different among communities, where HIGH $>$ T-MIX > LOW within and between sampling dates $(\mathrm{p}<0.05$; Fig. 1A). A similar pattern was observed for $T$ testudinum standing crop, except that there was no significant variation between T-MIX and LOW ( $p>0.05$; Fig. 1B). Mean changes in SS density between sampling dates were significant for LOW $(+65 \% ; p<0.05)$, but not for HIGH and MIX $(+2.5$ and $+9.8 \%$, respectively; $p>$ $0.05)$. Halodule wrightii had significantly higher SS densities than $T$. testudinum in MIX, and exhibited a $342 \%$ increase in SS density between sampling dates $(\mathrm{p}<0.05)$.

Lloyd's index of patchiness indicated that both species exhibit spatially clumped or aggregated distributions in MIX during both sampling events, with all values of $L$ ranging between 1.570 and 1.813 (Table 1). Interspecific interactions between Thalassia testudinum and Halodule wrightii were detected from the contingency table analysis and correlations, based on the spatial distribution of both species. The association strength $(V)$ of 0.28 between $T$. testudinum and $H$. wrightil was significant for both sampling dates $(p<0.05)$. This is interpreted as a strong interaction between the 2 species. The nature of this interspecific relationship may be competitive, as supported by negative correlations between $T$. testudinum and $H$. wrightii SS numbers in MIX communities for both October 1994 (Fig. 2A) and June 1995 (Fig. 2B). 
Table 1. Lloyd's ( $L$ ) index of patchiness for Thalassia testudinum and Halodule wrightii sampled in 5 intermixed sites (MIX). Values for means and variances were determined from the number of short shoots observed in $25 \mathrm{~cm}$ quadrats $(\mathrm{N}=100)$. Calculations for $L$ and determination of seagrass spatial distribution patterns are described in the text

\begin{tabular}{|lcccc|} 
& \multicolumn{2}{c}{ October 1994} & \multicolumn{2}{c|}{ June 1995 } \\
& T testudinum & H. wrightii & T testudinum & H. wrightii \\
\hline Mean & 8.13 & 15.28 & 9.81 & 67.62 \\
Variance & 40.30 & 177.38 & 52.48 & 2569.41 \\
$L$ & 1.695 & 1.813 & 1.607 & 1.570 \\
Spatial pattern & Clumped & Clumped & Clumped & Clumped \\
\hline
\end{tabular}

\section{Thalassia testudinum leaf characteristics and growth}

The number of blades (Fig. 3A) and 1-sided leaf area (Fig. 3B) on individual Thalassia testudinum SS did not significantly differ among communities and sampling dates $(p>0.05)$. There were significant differences for leaf area index (LAI) among communities and sampling dates, where HIGH > MIX > LOW, and LAIs were higher in June 1995 than October 1994 ( $\mathrm{p}<0.001$;

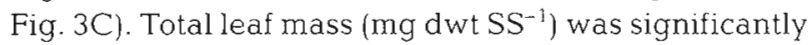
higher in LOW, relative to both HIGH and MIX ( $p=$ 0.009 ; Fig. 3D). The $46 \%$ increase in leaf mass observed in LOW between sampling dates ( $p=0.159$ ) included a $25 \%$ increase in the number of blades and a $64 \%$ increase in 1-sided leaf area. SS epiphytic biomass was highly variable, ranging between 82 and $481 \mathrm{mg} d w t$ $\mathrm{SS}^{-1}$, with a significant difference among communities $(p=0.046)$, but not between sampling dates $(p=0.648)$.

Thalassia testudinum shoot-specific productivity varied between 2.1 and $6.2 \mathrm{mg}$ dwt $\mathrm{SS}^{-1} \mathrm{~d}^{-1}$ in October 1994, and between 3.0 and $8.7 \mathrm{mg} \mathrm{dwt} \mathrm{SS}^{-1} \mathrm{~d}^{-1}$ in June 1995 (Fig. 4A). Significant differences for shoot-specific productivity were observed among communities, where LOW exhibited significantly higher rates than HIGH and MIX ( $p=0.002$ ). Differences between sampling dates were also significant $(p=0.003)$, as shootspecific productivity increased by an average of $35 \%$ from October 1994 to June 1995. Leaf relative growth rates ( $\mathrm{mg}$ dwt $\mathrm{g}^{-1} \mathrm{~d}^{-1}$ ) did not significantly differ among communities $(\mathrm{p}=0.081)$, but did vary between sampling dates ( $p=0.002$; Fig. $4 B$ ). This was primarily due to a $58 \%$ increase in MIX relative to minimal changes of -1.1 and $5.1 \%$ in HIGH and LOW, respectively. Areal productivity rates ( $g$ dwt $\mathrm{m}^{-2} \mathrm{~d}^{-1}$ ) significantly varied among communities ( $p<0.001)$ with HIGH exhibiting the greatest rates (Fig. 4C). Changes in areal productivity rates from October 1994 and June 1995 were also significant ( $p<0.001$ ), with an average increase $>73 \%$. Shoot-specific productivity and leaf mass were negatively correlated with SS density for both sampling dates (Fig. 5A to D); however, shootspecific productivity was not significantly related to SS density in October 1994 (Fig. 5B).

\section{Sediment characteristics}

Total sediment organic matter (\%) ranged between 1.2 and $4.8 \%$ for all communities sampled in March and June 1995 (Fig. 6A), and no significant differences were observed among communities ( $p>0.05$ ). Total sediment $\mathrm{NH}_{4}{ }^{+}$ranged between 5.2 and $17.0 \mathrm{mmol}$ $\mathrm{NH}_{4}{ }^{+} \mathrm{g}^{-1}$ wet sediment for both March and June 1995
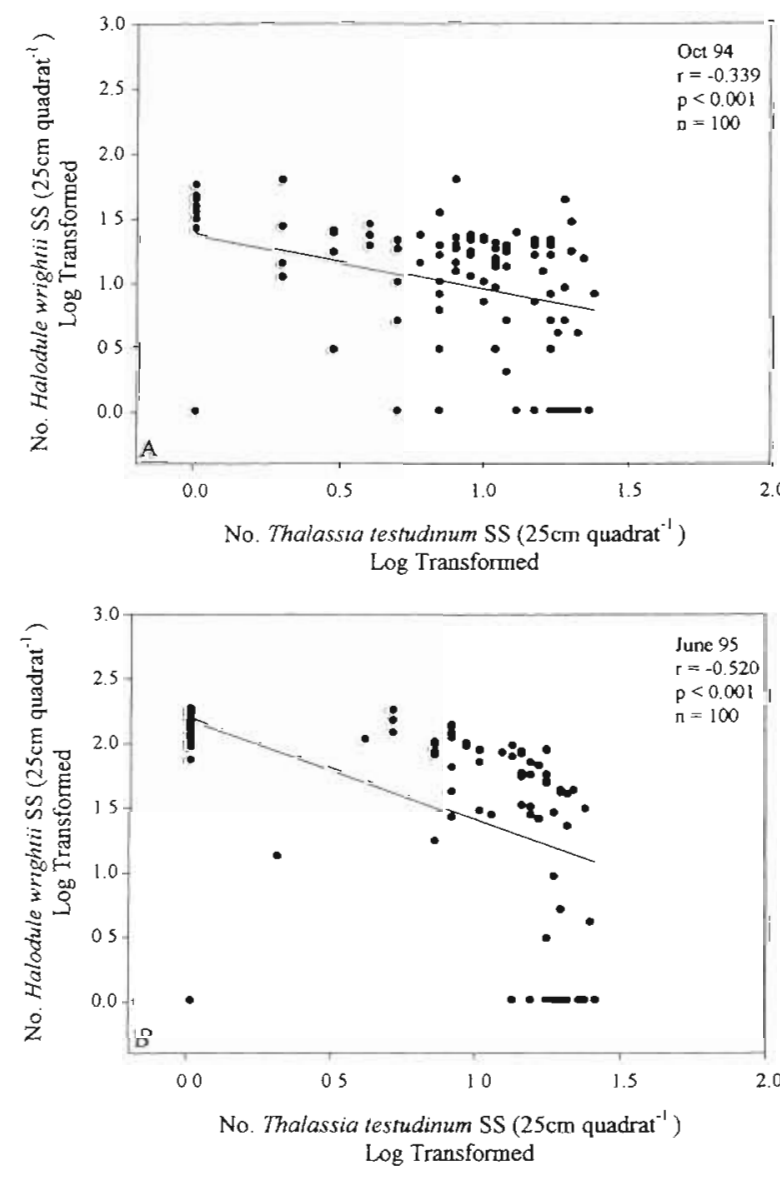

Fig. 2. Relationship between the number of Thalassia testudinum and Halodule wrightii SS sampled in 100 quadrats $(25 \mathrm{~cm})$ from all 5 MIX sites in both (A) October 1994 and (B) June 1995 

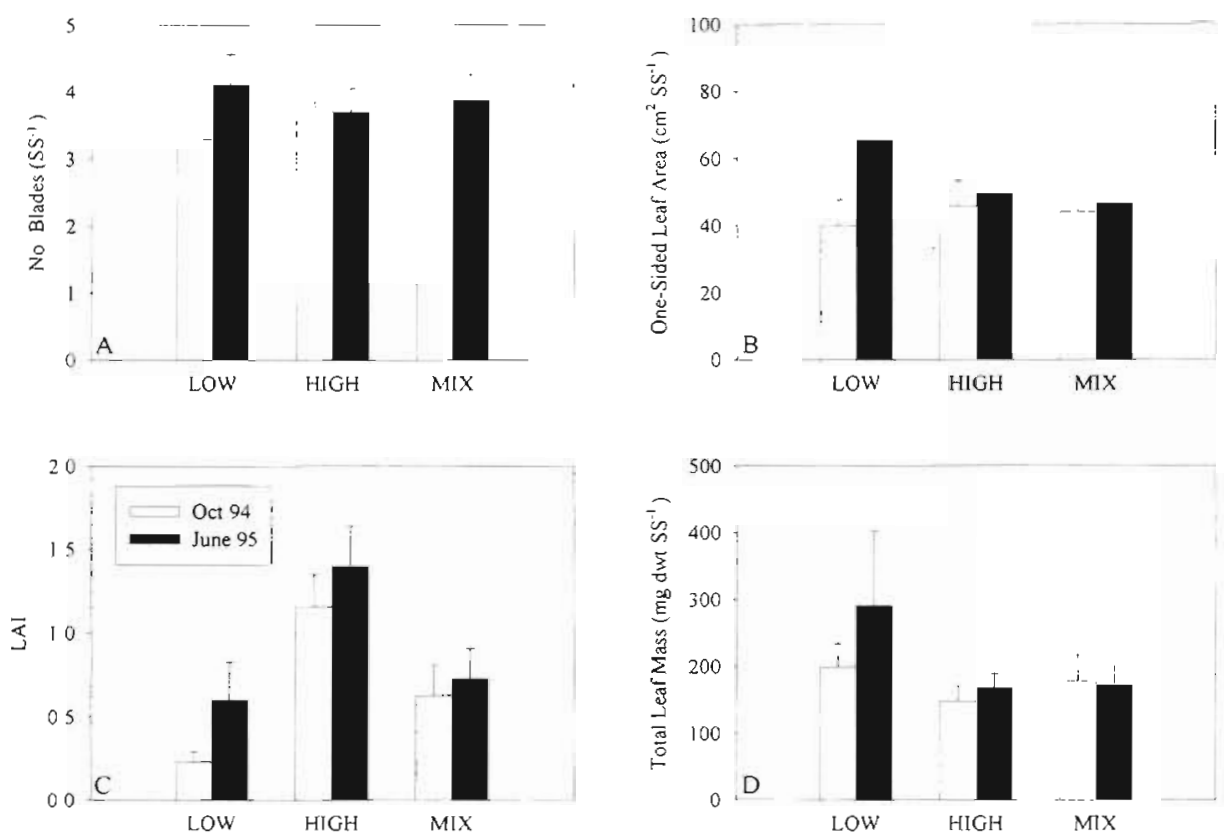

Fig. 3. Mean (+1 SD) (A) no. of blades, (B) 1-sided leaf area, (C) leaf area index (LAI), and (D) total leaf mass, of Thalassia testudinum sampled from LOW, HIGH, and MIX communities in October 1994 and June 1995
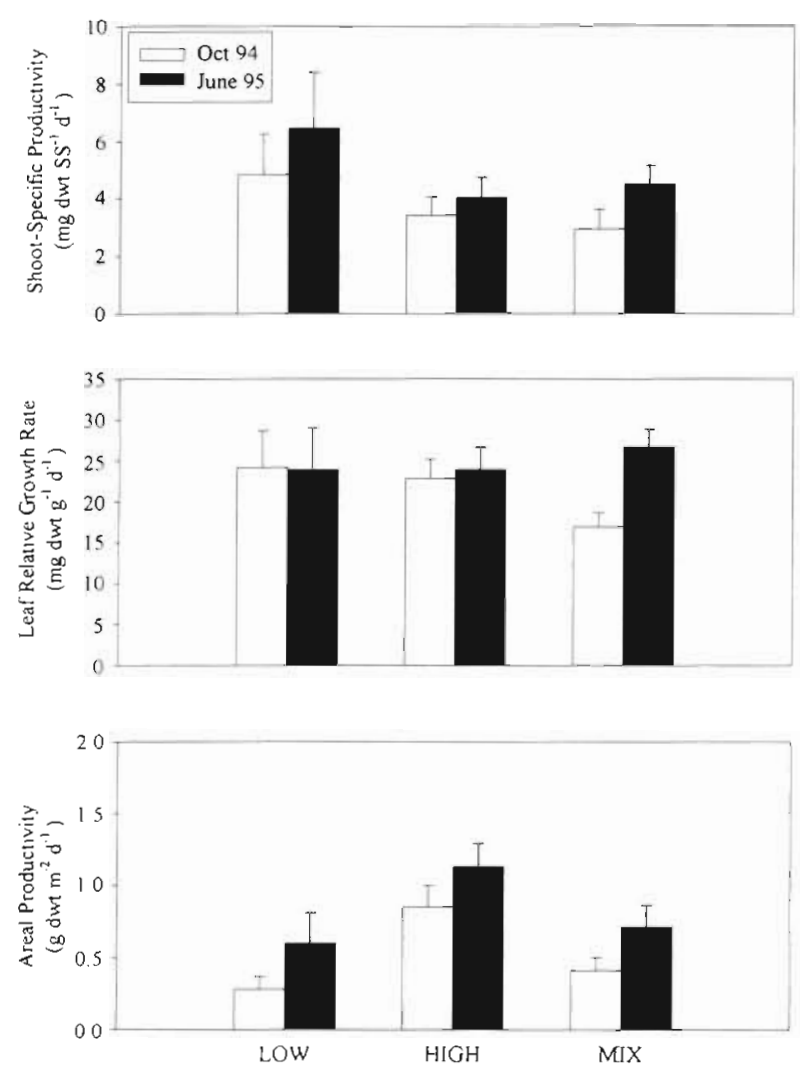

Fig. 4. Mean (+1 SD) (A) shoot-sperific, (B) leaf relative growth rate, and (C) areal productivity of Thalassia testudinum sampled from LOW. HIGH, and MIX communities in October 1994 and June 1995 collections (Fig. 6B). Significant differences were observed among communities, where HIGH > MIX > LOW in March and HIGH > MIX > LOW in June. Total sediment $\mathrm{NH}_{4}{ }^{+}$in cores collected from Halodule wrightii monocultures (HW) in March were only significantly different from LOW. Total sediment $\mathrm{PO}_{4}{ }^{3-}$ for individual sites ranged between 0.17 and $0.61 \mu \mathrm{mol}$ $\mathrm{PO}_{4}{ }^{3-} \mathrm{g}^{-1}$ wet sediment (Fig. 6C). Significant trends among communities were similar for both sampling dates, where MIX $\approx \mathrm{HW}>\mathrm{HIGH}>\mathrm{LOW}$.

\section{Thalassia testudinum elemental and isotopic composition}

Elemental composition of Thalassia testudinum leaves did not vary among communities for $\mathrm{C}$ or $\mathrm{P}$, but leat $N$ content in LOW was significantly lower than HIGH and MIX (Table 2). Differences in leaf $\mathrm{N}$ content among communities were also reflected in the differences in leaf $C: N$ and N:P ratios. $\delta^{13} \mathrm{C}$ and $\delta^{15} \mathrm{~N}$ values were fairly consistent among individual sites, with ranges of 2.2 and $3.4 \%$, respectively. LOW had significantly heavier isotopic values for both $\delta^{13} \mathrm{C}$ and $\delta^{15} \mathrm{~N}(p<0.05 ;$ Table 2$)$, which suggests that there are differences among the communities with respect to $\mathrm{C}$ and $\mathrm{N}$ sources, and/or utilization by $T$. testudinum. Sediment $\mathrm{NH}_{4}{ }^{+}$is significantly correlated with SS density, leaf C:N, and leaf $\mathrm{N}: \mathrm{P}(\mathrm{p}<0.05$; Fig $7 \mathrm{~A}$ to $\mathrm{C})$, whereas sediment $\mathrm{PO}_{4}{ }^{3-}$ is not significantly correlated 
with SS density, leaf $C: P$, and leaf $N: P(p>0.05$; Fig. 7D to F).

\section{Thalassia testudinum daily nutrient demands}

LOW exhibited a greater leaf nutrient content for both nitrogen (Table 3) and phosphorus (Table 4), and experienced the greatest nutrient demands for both $\mathrm{N}$ and $\mathrm{P}$ on a per SS basis; however, these differences were only significant for daily $\mathrm{P}$ demands on a per SS basis ( $p=0.025)$. HIGH exhibited a significantly greater nutrient content in the total standing crop for both nu- trients, and had the highest nutrient demands for $\mathrm{N}$ and $P$ on an areal basis (Tables $3 \& 4$ ). No significant differences were observed for daily nutrient demands based on leaf relative growth rates ( $\mathrm{mg} \mathrm{N}$ or $\mathrm{P} \mathrm{g}^{-1}$ leaf).

\section{DISCUSSION}

Growth of Thalassia testudinum in Cockroach Bay exhibited similar seasonal trends and ranges relative to other areas in Cockroach Bay (Dawes et al. 1997), Tampa Bay (Dawes 1981), Florida Bay (Zieman et al. 1989), Florida Keys (Tomasko \& Lapointe 1991), and Mexico
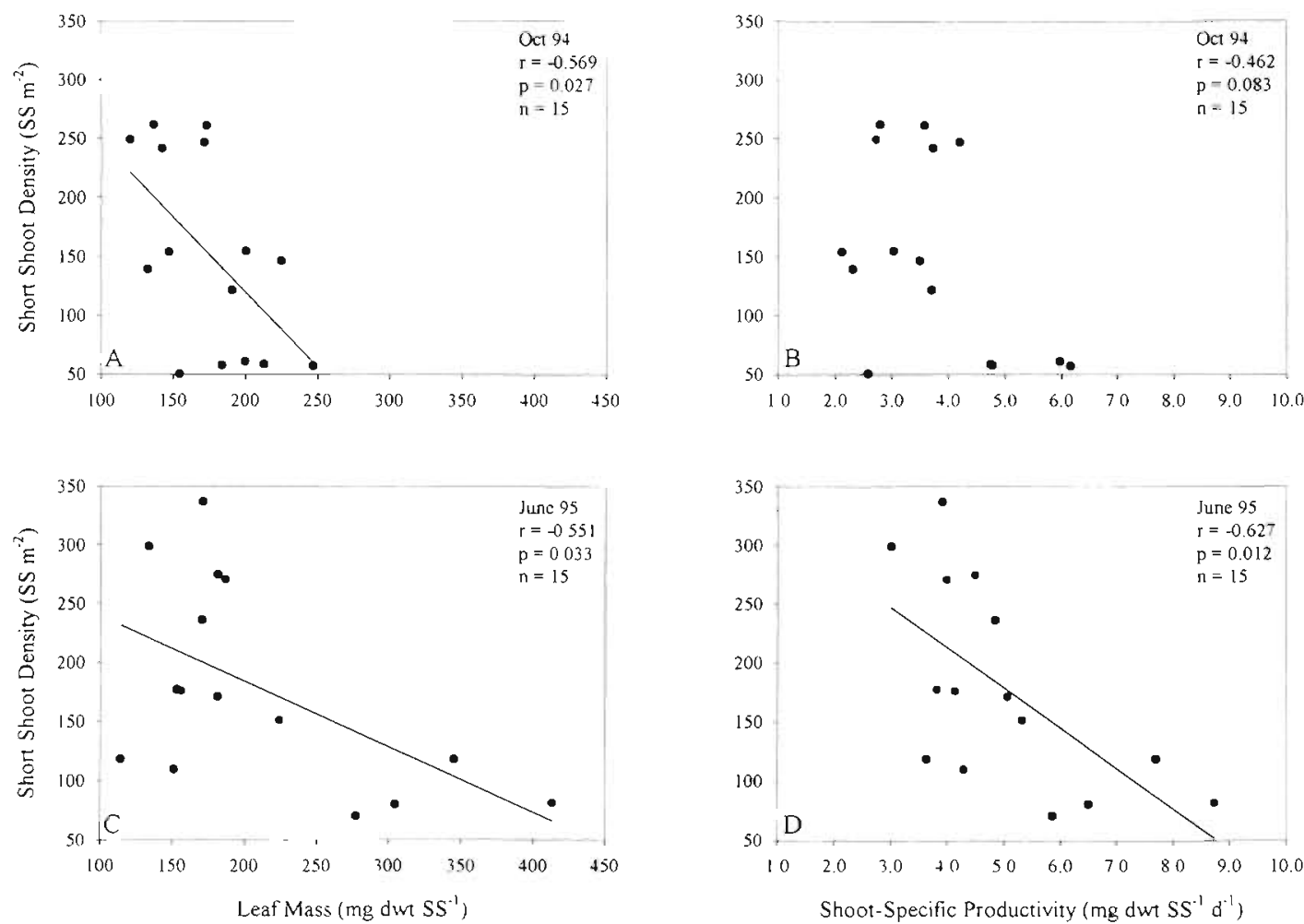

Fig. 5. Relationship between SS density with leaf mass and shoot-specific productivity of Thalassia testudinum sampled from LOW, HIGH, and MIX communities in October 1994 and June 1995. Values are site means

Table 2. Mean ( \pm 1 SD) elemental and stable isotope composition of Thalassia testudinum leaf material collected from 3 seagrass communities (LOW. HIGH, MIX) in June 1995. C:N:P ratios are presented as mol:mol, and stable isotopes in \%. Differences between communities were tested with a 1 -way ANOVA, and pairwise comparisons were made with the Student-Newman-Keuls method. Significant differences among communities ( $p \leq 0.05$ ) are denoted by superscripts

\begin{tabular}{|c|c|c|c|c|c|c|c|c|}
\hline & $\% \mathrm{C}$ & $\% \mathrm{~N}$ & $\% \mathrm{P}$ & $C: N$ & $\mathrm{C}: \mathrm{P}$ & $N: P$ & ${ }^{13} \mathrm{C}$ & ${ }^{15} \mathrm{~N}$ \\
\hline LOW & $36.57 \pm 0.47$ & $1.93 \pm 0.13^{a}$ & $0.41 \pm 0.02$ & $22.13 \pm 1.32^{a}$ & $230.84 \pm 8.35$ & $10.48 \pm 0.73^{a}$ & $-15.08 \pm 0.70^{\mathrm{a}}$ & $-0.70 \pm 0.51^{a}$ \\
\hline $\mathrm{HIGH}$ & $36.52 \pm 0.72$ & $2.33 \pm 0.16^{b}$ & $0.43 \pm 0.01$ & $18.29 \pm 0.90^{\prime \prime}$ & $220.80 \pm 6.65$ & $12.12 \pm 0.83^{\prime \prime}$ & $-15.96 \pm 0.33^{b}$ & $0.21 \pm 0.86^{b}$ \\
\hline MIX & $36.42 \pm 0.38$ & $2.19 \pm 0.18^{b}$ & $0.42 \pm 0.01$ & $19.55 \pm 1.68^{b}$ & $224.30 \pm 7.74$ & $11.56 \pm 1.19^{\mathrm{db}}$ & $-15.85 \pm 0.37 b$ & $1.12 \pm 0.53^{c}$ \\
\hline$F_{2,12}$ & 0.109 & 8.213 & 2.323 & 10.658 & 2.399 & 3.968 & 4.72 & 9.67 \\
\hline $\mathrm{p}$ & 0.898 & 0.006 & 0.140 & 0.002 & 0.149 & 0.048 & 0.031 & 0.003 \\
\hline
\end{tabular}



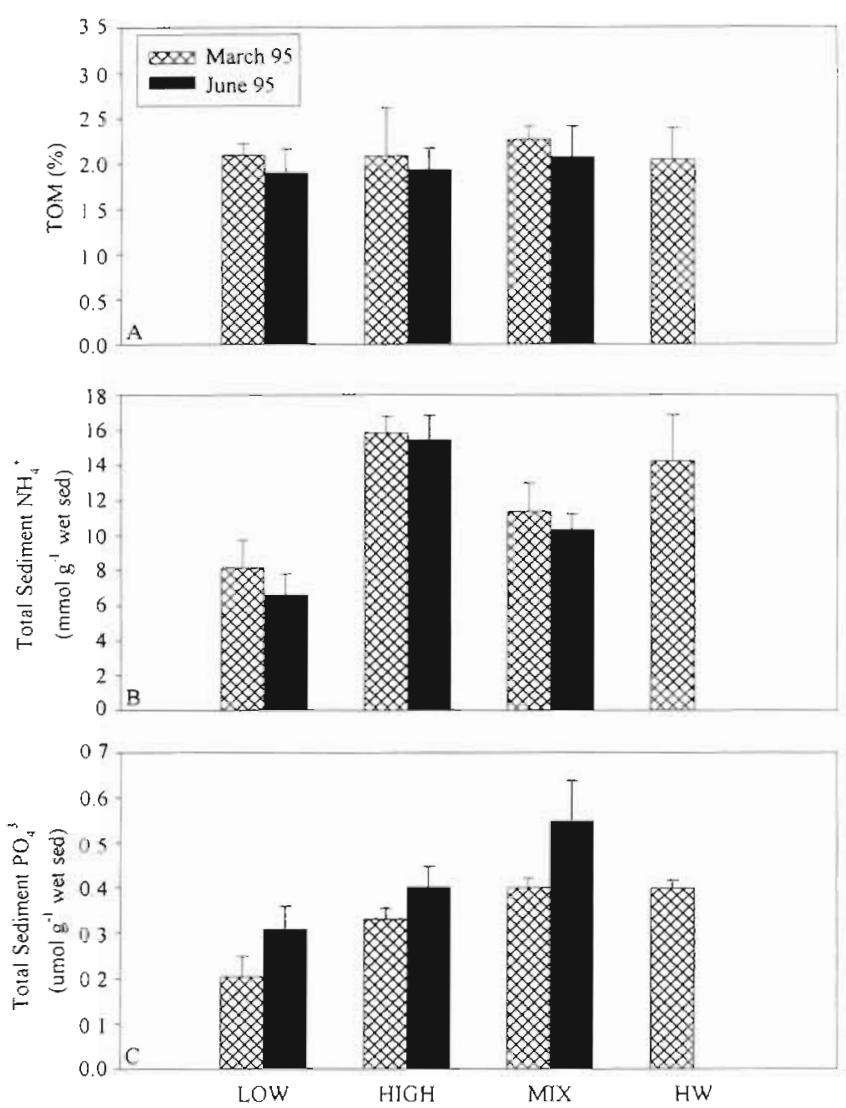

Fig. 6. Mean (+1 SD) (A) total organic matter (TOM), (B) total extractable $\mathrm{NH}_{4}{ }^{+}$, and $(\mathrm{C})$ total extractable $\mathrm{PO}_{4}{ }^{3-}$ sampled from LOW, HIGH, MIX, and HW in March and June 1995. Note that HW was only sampled in March 1995

(Tussenbroek 1995). Observations from the present study also suggest that seagrass growth may vary with community structure, although significant differences among communities were not consistent. Shoot-specific productivity rates were greatest in LOW, relative to HIGH and MIX. Leaf relative growth rates did not significantly differ among communities across both sampling dates, and areal productivity was significantly greater in HIGH, relative to LOW and MIX. These disparities are primarily due to differences among communities in individual SS leaf mass and density.

The effects of community structure appear to play an important role in regulating the size and growth of Thalassia testudinum in a heterogeneous environment. Intraspecific competition in seagrass communities has not been widely studied. South (1983) observed relatively higher rates of leaf growth in $T$. testudinum in a low-density grass bed relative to areas of higher density in Bermuda, and differences in $T$. testudinum leaf growth rates with respect to density have also been observed in northwest Florida (Vargas \& Miller unpubl. data). In the absence of space limitation, intraspecific competition for nutrients and light may explain the differences observed in $T$. testudinum leaf characteristics, growth, and C:N:P and isotopic composition between LOW and HIGH in Cockroach Bay. It is generally accepted as plant density increases leaf canopy thickness also increases and light availability is reduced (Harper 1977, Tilman 1988, Bazzaz 1996). T. testudinum growing in $\mathrm{HIGH}$ may have been lightlimited due to the effects of self-shading. This may explain the negative correlations between leaf mass and shoot-specific growth with SS density, and the significantly higher shoot-specific growth rates observed in LOW. Negative correlations between plant mass and density are referred to as competition-density effects (Kira et al. 1953), and have been observed elsewhere (Firbank \& Watkinson 1990). In the context of the self-thinning rule, seagrasses are clonal plants in which individual SS (or ramets) along a genet are physiologically integrated (Tomasko \& Dawes 1989), thus having the benefits of shared resources. When the number of genets increase, ramet performance (i.e. growth, size) may decrease-although this relationship is not firmly established (Antonivics \& Levin 1980, Firbank \& Watkinson 1990). In the present study, we did not attempt to count the number of genets due to the depth of the rhizomes and the high degree of intermixing within the rhizome mat.

Table 3. Mean ( $\pm 1 \mathrm{SD}$ ) leaf content and daily demand of nitrogen for Thalassia testudinum collected from 3 seagrass communities (LOW, HIGH, MIX) in June 1995. Differences between communities were tested with a 1-way ANovA and pairwise comparisons were made with the Student-Newman-Keuls method. Significant differences among communities $(p \leq 0.05)$ are denoted by superscripts

\begin{tabular}{|c|c|c|c|c|c|}
\hline & $\begin{array}{l}\text { N leaf content } \\
\left(\mathrm{mg} \mathrm{N} \mathrm{SS}^{-1}\right)\end{array}$ & $\begin{array}{l}N \text { in standing crop } \\
\left(g \mathrm{~N} \mathrm{~m}^{-2}\right)\end{array}$ & $\begin{array}{c}\text { Daily } N \text { demand } \\
\quad\left(\mathrm{mg} \mathrm{N} \mathrm{SS}^{-1}\right)\end{array}$ & $\begin{array}{c}\text { Daily } N \text { demand } \\
\text { (mg } \mathrm{Ng}^{-1} \text { leaf) }\end{array}$ & $\begin{array}{l}\text { Daily } \mathrm{N} \text { demand } \\
\quad\left(\mathrm{mg} \mathrm{N} \mathrm{m}^{-2}\right)\end{array}$ \\
\hline LOW & $5.56 \pm 2.05$ & $0.50 \pm 0.18^{\circ}$ & $0.12 \pm 0.03$ & $0.47 \pm 0.56$ & $11.32 \pm 3.21^{a}$ \\
\hline $\mathrm{HIGH}$ & $3.93 \pm 0.55$ & $1.11 \pm 0.16^{b}$ & $0.09 \pm 0.02$ & $0.56 \pm 0.06$ & $26.19 \pm 2.75^{\mathrm{b}}$ \\
\hline MIX & $3.76 \pm 0.57$ & $0.59 \pm 0.13^{\mathrm{a}}$ & $0.10 \pm 0.02$ & $0.59 \pm 0.10$ & $15.37 \pm 3.34^{\mathrm{a}}$ \\
\hline$F_{2,12}$ & 3.09 & 22.10 & 2.39 & 2.87 & 30.50 \\
\hline p & 0.083 & $<0.001$ & 0.134 & 0.096 & $<0.001$ \\
\hline
\end{tabular}



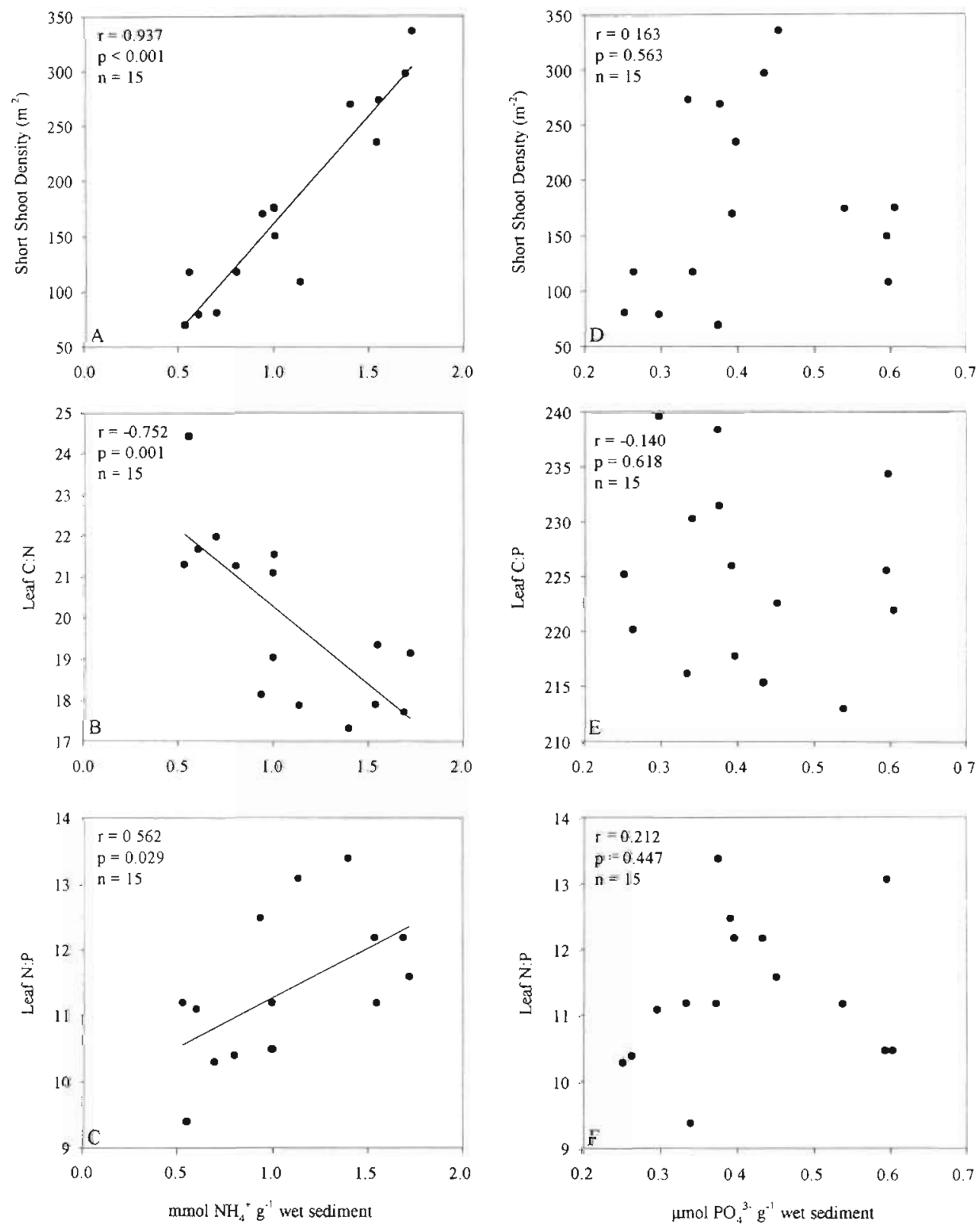

Fig. 7. Relationship between sediment $\mathrm{NH}_{4}{ }^{+}$and $\mathrm{PO}_{4}{ }^{3-}$ with SS density and leaf $\mathrm{C}: \mathrm{N}: \mathrm{P}$ of Thalassia testudinum for all sites sampled in LOW, HIGH, and MIX communities in June 1995. Values are site means

Table 4. Mean ( $\pm 1 \mathrm{SD}$ ) leaf content and daily demand of phosphorus for Thalassia testudinum collected from 3 seagrass communities (LOW, HIGH, MIX) in June 1995. Differences between communities were tested with a 1-way ANOVA and pairwise comparisons were made with the Student-Newman-Keuls method. Significant differences among communities $(p \leq 0.05)$ are denoted by superscripts

\begin{tabular}{|lccccc|}
\hline & $\begin{array}{c}\text { P leaf content } \\
\left(\mathrm{mg} \mathrm{P} \mathrm{S}^{-1}\right)\end{array}$ & $\begin{array}{c}\text { P in standing crop } \\
\left(\mathrm{g} \mathrm{P} \mathrm{m}^{-2}\right)\end{array}$ & $\begin{array}{c}\text { Daily P demand } \\
\left(\mathrm{mg} \mathrm{P} \mathrm{SS}^{-1}\right)\end{array}$ & $\begin{array}{c}\text { Daily P demand } \\
\left(\mathrm{mg} \mathrm{P} \mathrm{g}^{-1} \text { leaf }\right)\end{array}$ & $\begin{array}{c}\text { Daily P demand } \\
\left(\mathrm{mg} \mathrm{P} \mathrm{m}^{-2}\right)\end{array}$ \\
\hline LOW & $1.37 \pm 0.62$ & $0.12 \pm 0.05^{\mathrm{d}}$ & $0.030 \pm 0.012^{\mathrm{a}}$ & $0.111 \pm 0.031$ & $2.75 \pm 0.96^{\mathrm{a}}$ \\
HIGH & $0.72 \pm 0.08$ & $0.21 \pm 0.03^{\mathrm{b}}$ & $0.017 \pm 0.003^{\mathrm{b}}$ & $0.102 \pm 0.012$ & $4.81 \pm 0.62^{\mathrm{b}}$ \\
MIX & $0.73 \pm 0.13$ & $0.12 \pm 0.03^{\mathrm{d}}$ & $0.019 \pm 0.003^{\mathrm{b}}$ & $0.112 \pm 0.007$ & $2.97 \pm 0.66^{\mathrm{a}}$ \\
$F_{2,12}$ & 4.02 & 8.44 & 5.12 & 0.374 & 11.00 \\
p & 0.046 & 0.005 & 0.025 & 0.696 & 0.002 \\
\hline
\end{tabular}


Trends in Thalassia testudinum leaf C:N:P and isotopic composition are similar to those observed by Abal et al. (1994) and Grice et al. (1996). They reported that with high light availability, seagrass leaf mass and growth rates increased, concurrently, with an increase in leaf $\mathrm{C}: \mathrm{N}$ and $\delta^{13} \mathrm{C}$ in response to higher $\mathrm{N}$ and $\mathrm{C}$ demands. Significant differences in seagrass leaf $\delta^{13} \mathrm{C}$ have been attributed to light availability, presumably due to increased growth rates, $\mathrm{C}$ demands, and reduced discrimination of heavier $\mathrm{C}$ isotopes (Cooper \& DeNiro 1989, Durako \& Hall 1992). Thus, relatively lower leaf mass (mg dwt $\mathrm{SS}^{-1}$ ) and shoot-specific growth rates of $T$. testudinum in HIGH and MIX may be the result of low light availability from self-shading The leaf $\mathrm{C}: \mathrm{N}$ and $\delta^{13} \mathrm{C}$ content is consistent with what is known regarding the relationship among light availability, leaf mass, leaf growth, and $\mathrm{N}$ and $\mathrm{C}$ demands.

Thalassia testudinum may also be adversely affected by Halodule wrightii. Spatial patterns in MIX suggest that $T$. testudinum and $H$. wrightii are interacting in a way that limits the other's density. SS densities of $T$. testudinum were negatively correlated with SS densities of $H$. wrightii, and exhibited a significantly lower increase between sampling dates relative to LOW $(+9.8$ to $+65 \%$, respectively $)$. The typical range of seasonal increases in $T$. testudinum SS densities in Cockroach Bay is between 60 and $120 \%$ (Dawes \& Ehringer 1994), but is still substantially less than those observed for $H$. wrightii in this study. Significant values of the association strengths $(V)$ between $T$. testudinum and $H$. wrightii provide additional evidence for interspecific interactions in MIX.

While spatial analyses are good descriptors of community structure, they do not provide information about the intensity or importance of the interactions, or the mechanisms involved. Competition for space may be minimized by stratification of root-rhizome systems, as reported for mixed communities of Thalassia testudinum and Halodule wrightii (Patriquin 1972, Williams 1990). Agawin et al. (1996) observed speciesspecific nutrient deficiencies between the seagrasses Thalassia hemprichii (Ehrenberg) Ascherson and Enhalus acoroides (Linnaeus f.) Royle in the Philippines. This may also have been due to the segregation of root-rhizome systems. Biomass cores collected in October 1994 and June 1995 from MIX did not exhibit any interspecific differentiation in stratification with. respect to sediment depth, even though $H$. wrightii rhizomes were never found deeper than $5 \mathrm{~cm}$ (Rose 1996).

Interspecific competition for light also does not appear to be a structuring force in these shallow, intermixed communities. Halodule wrightii is relatively more shade-tolerant and persists in the understory of Thalassia testudinum and other seagrasses (Wiginton \& McMillian 1979, Iverson \& Bittaker 1986, Four- qurean et al. 1995), and its relatively smaller size in Cockroach Bay would not produce a light-limiting canopy for $T$. testudinum (authors' pers, obs.). In nutrient-limited systems, $T$. testudinum is competitively dominant (Williams 1990, Fourqurean et al. 1992b, 1995). However, when $H$. wrightii is released from nutrient limitation, it has the ability to produce aerial runners that rise above and shade the underlying $T$. testudinum, which eventually results in the competitive exclusion of $T$. testudinum from areas of high nutrient availability (Fourqurean et al. 1995). In Cockroach Bay, the production of aerial runners by $H$. wrightii has not been observed, despite high nutrient levels.

Interspecific competition for sediment nutrients also does not appear to be an important interaction between these species in Cockroach Bay. Halodule wrightii has higher nutrient requirements than Thalassia testudinum (Fourqurean et al. 1992b), and correlations between $H$. wrightii SS densities and $T$. testudinum leaf tissue $C: N$ and $C: P$ in MIX are not significant $(p>0.05)$. However, the role and importance of sediment nutrients to $T$. testudinum in Cockroach Bay need to be further investigated because significant differences in sediment nutrients and $T$. testudinum leaf C:N:P were observed among communities. Sediment nutrient concentrations do not truly represent nutrient availability, due to the inability of plants and other primary producers to utilize nutrients sorbed to sediment clays and mineral complexes (Smith 1984, Chambers \& Fourqurean 1991). Leaf tissue elemental ratios present a more accurate indicator of plant nutrient availability for several reasons: nutrient demands can be calculated from productivity rates and leaf $\mathrm{N}$ and $\mathrm{P}$ composition, retention time of nutrients is longer in plant tissue relative to sediments, and variations in C:N:P ratios can be used to infer nutrient limitation (Gerloff \& Krombholz 1966, Atkinson \& Smith 1983, Duarte 1990, Fourqurean et al. 1992a). Nutrient concentrations measured concurrently with leaf tissue elemental composition provide the necessary tools to describe the relationship between environmental availability and plant demands. In the present study, a significant negative correlation was observed between total sediment $\mathrm{NH}_{4}{ }^{+}$and $T$. testudinum leaf tissue $\mathrm{C}: \mathrm{N}$, but not between total sediment $\mathrm{PO}_{4}{ }^{3-}$ and leaf $\mathrm{C}: \mathrm{P}$ This suggests that there is a relationship between plant nutrient demands and environmental concentrations for $\mathrm{N}$, but not for $\mathrm{P}$. This is not surprising, considering that Tampa Bay is known for having extremely high $\mathrm{PO}_{4}{ }^{3-}$ concentrations due to naturally high background levels, discharges from phosphate mining and chemical processing, and point and non-point source eutrophication (Fanning \& Bell 1985). Leaf tissue \% P were $2 \times$ the reported mean and 
median values for seagrasses (Duarte 1990), and leaf C:P ratios were substantially less than those reported by Atkinson \& Smith (1983) for seagrasses and by Faganeli et al. (1986) for benthic marine algae. The minimal role of $\mathrm{P}$ availability is also supported by the lack of any significant relationships between sediment $\mathrm{PO}_{4}{ }^{3-}$ and $\mathrm{C}: \mathrm{P}$ with any other seagrass community, morphological, or physiological parameter.

Thalassia testudinum leaf N:P ratios were $<16$, which is indicative of N-limitation (Redfield 1958, Smith 1984). Lower leaf $C: N$ and higher \% $N$ values have been reported elsewhere for $T$. testudinum (Patriquin 1972, Atkinson \& Smith 1983, Duarte 1990 Fourqurean et al. 1992a,b), thus suggesting that there is a greater potential for $N$ uptake by $T$. testudinum than what we observed in the present study. This is also evident from differences among communities in Cockroach Bay. High shoot-specific growth rates in LOW, coupled with the lowest leaf $\% \mathrm{~N}$, highest C:N, and lowest $N: P$, suggest that daily $N$ demands are not being met - despite the high rates of growth exhibited by $T$. testudinum in these communities. Perhaps lowerthan-expected values for daily nitrogen demand (on a per SS basis) in LOW may be attributed to problems associated with describing seagrass nutrient demands solely on the basis of leaf characteristics, or $\mathrm{N}$ availability in LOW is lower relative to $\mathrm{HIGH}$ and MIX which corresponds to our measurements of lower sediment $\mathrm{NH}_{4}{ }^{+}$in LOW. However, due to extremely high sediment $\mathrm{NH}_{4}{ }^{+}$and $\mathrm{PO}_{4}{ }^{3-}$ within Cockroach Bay (see also Dawes et al. 1997), seagrasses in Cockroach Bay are most likely not to be nutrient limited. Low leaf N:P ratios may be due to abnormally high $\mathrm{P}$ availability. High sediment $\mathrm{NH}_{4}{ }^{+}$in $\mathrm{HIGH}$ most likely derives from the established relationship between plants and soil/sediment nutrient cycles observed in both terrestrial (Greig-Smith 1979, Gibson 1988) and aquatic systems (Barko \& Smart 1980, Hemminga et al. 1991). Seagrass meadows accumulate sediment $\mathrm{NH}_{4}{ }^{+}$by trapping small organics from the water column and reducing $\mathrm{NH}_{4}{ }^{+}$fluxes out of the sediment via an increased benthic boundary layer due to a dense blade canopy (Kenworthy et al. 1982, Short 1983, Dennison et al. 1987). Thus, high sediment $\mathrm{NH}_{4}^{+}$in $\mathrm{HIGH}$ appears to be the result of high seagrass density. Low leaf $\mathrm{C}: \mathrm{N}$ ratios in $\mathrm{HIGH}$ may be responding to either the extra supply of $N$, or the reduced leaf growth and nutrient demands experienced by individual SS. Variations in $T$. testudinum leaf $\delta^{15} \mathrm{~N}$ among communities also suggest that seagrass nutrient dynamics may exhibit community-level differences with respect to sources, sinks, and internal recycling (Nadelhoffer \& Fry 1994). Therefore, despite several trends in the data, it would be premature to make any definitive conclusions about the relationship between seagrass community structure, nutrient demands, and sediment nutrient dynamics due to the number of interacting variables involved-many of which were outside the scope of this study.

The effects of community structure on plants may not always involve intra- or interspecific competition, and/ or localized changes in resource regimes. In Cockroach Bay, Thalassia testudinum leaf characteristics, productivity, and $\mathrm{C}: \mathrm{N}: \mathrm{P}$ and stable isotopic composition appear to be negatively affected by intraspecific competition (possibly for light) and interspecific interactions with Halodule wrightii. However, though we observe patterns that support the role and importance of competitive interactions, other processes cannot be ignored. For example, low-density communities with high growth rates will not consistently have low densities unless other factors are involved - such as localized disturbances and stresses. Because Cockroach Bay is heavily affected by boat propeller scars (see Dawes et al. 1997), the structure of the present-day communities identified in this study (i.e. LOW, HIGH, MIX, and HW) may be the result of past events. Potentially, the heterogeneous landscape observed in Cockroach Bay may represent different successional stages of seagrass meadows in this system. These differences in community structure, due to either ecosystem history or community-level processes, may also influence other factors including: current patterns, drift algae composition, epiphyte loads, and the presence and activity of herbivores and other fauna. Thus, we should use caution and not allow our simplified preconceptions to be misdirected by apparent patterns in community structure or competition (en sensu Holt 1977) that may often mask a more complex web of interactions and factors.

Acknowledgements. The authors would like to thank John Andorfer, Jeff Bryan, Chris Komnath, Manuel Merello, Kathie Siar, and Dorothy Stevens, for field and laboratory assistance; Peter Stiling for use of his leaf area meter; Bill Gilhooly and Brain Fry for analyzing the seagrass leaf stable isotopes; and Susie Escorcia for processing the seagrass leaf elemental analyses. This paper has been substantially improved via many discussions and helpful comments from Chris Buzzelli and Jim Fourqurean. This study was partially funded by the Department of Biology at the University of South Florida. This is contribution no. 103 of the Southeast Environmental Research Program at FIU.

\section{LITERATURE CITED}

Abal EG, Loneragan N, Bowen P, Perry CJ, Udy JW, Dennison WC (1994) Physiological and morphological responses of the seagrass Zostera capricorni Aschers to light intensity. J Exp Mar Biol Ecol 178:113-129

Agawin NSR, Duarte CM, Fortes MD (1996) Nutrient limitation of Philippine seagrasses (Cape Bolinao, NW Philip- 
pines): in situ experimental evidence. Mar Ecol Prog Ser 138:233-243

Antonovics J, Levin DA (1980) The ecological and genetic consequences of density-dependent regulation. Annu Rev Ecol Syst 11:411-452

Atkinson MJ, Smith SV (1983) C:N:P ratios of benthic marine plants, Limnol Oceanogr 28:568-574

Barko JW, Smart RM (1980) Mobilization of sediment phosphorus by submersed freshwater macrophytes. Freshw Biol 10:229-238

Bazzaz FA (1996) Plants in changing environments: linking physiological, population, and community ecology. Cambridge University Press, Cambridge

Bremmer JW (1965) Inorganic forms of nitrogen. In: Black CA (ed) Methods of soil analysis, Part 2. American Society of Agronomy Inc, Madison, WI, p 1179-1232

Chambers RM, Fourqurean JW (1991) Alternative criteria for assessing nutrient limitation of a wetland macrophyte (Peltandra virginica (L.) Kunth). Aquat Bot 40:305-320

Connell JH (1983) On the prevalence and relative importance of interspecific competition: evidence from field experiments. Am Nat 122:661-696

Connell JH (1990) Apparent versus 'real' competition in plants. In: Grace JB, Tilman D (eds) Perspectives on plant competition. Academic Press, San Diego, p 9-26

Cooper LW, DeNiro MJ (1989) Stable carbon isotope variability in the seagrass Posidonia oceanica: evidence for light intensity effects. Mar Ecol Prog Ser 50:225-229

Dawes CJ (1981) Marine botany. John Wiley and Sons, New York

Dawes CJ, Ehringer N (1994) Recovery of the seagrass Thalassia testudinum into boat propeller cuts in Cockroach Bay: two-year report. Environmental Protection Commission, Hillsborough County, FL

Dawes CJ, Andorfer JH, Rose CD, Uranowski C, Ehringer N (1997) Regrowth of the seagrass Thalassia testudinum into propeller scars. Aquat Bot 59:139-155

Dennison WC, Aller RC, Alberte RS (1987) Sediment ammonium availability and eelgrass (Zostera marina) growth. Mar Biol 94:469-477

Duarte CM (1990) Seagrass nutrient content. Mar Ecol Prog Ser 67:201-207

Duarte CM (1995) Submerged aquatic vegetation in relation to different nutrient regimes. Ophelia 41:87-112

Durako MJ, Hall MO (1992) Effects of light on the stable carbon isotope composition of the seagrass Thalassia testudinum. Mar Ecol Prog Ser 86:99-101

Erftemeijer PLA, Herman PMJ (1994) Seasonal changes in environmental variables, biomass, production and nutrient contents in two contrasting tropical intertidal seagrass beds in South Sulawesi, Indonesia. Oecologia 99:45-59

Faganeli $J$, Vukovič A, Saleh FI, Pezdič J (1986) C:N:P ratios and stable carbon and hydrogen isotopes in the benthic marine algae, Ulva rigida C. Ag. and Fucus virsoides J, Ag. J Exp Mar Biol Ecol 102:153-166

Fanning KA, Bell LM (1985) Nutrients in Tampa Bay. In: Treat SF, Simon JL, Lewis RR III, Whitman. RL Jr (eds) Proceedings, Tampa Bay area scientific information symposium (May 1982). Burgess Publishing Co, MN, p 109-1.29

Firbank LG, Watkinson AR (1990) On the effects of competition: from monocultures to mixtures. In: Grace JB, Tilman D (eds) Perspectives on plant competition. Academic Press, San Diego, p 165-192

Fourqurean JW, Zieman JC, Powell GVN (1992a) Phosphorus Iimitation of primary production in Florida Bay: evidence from C:N:P ratios of the dominant seagrass Thalassia testudinum. Limnol Oceanogr 37:162-171
Fourqurean JW, Zieman JC, Powell GVN (1992b) Relationships between porewater nutrients and seagrasses in a subtropical carbonate environment. Mar Biol 114:57-65

Fourqurean JW, Powell GVN, Kenworthy WJ, Zieman JC (1995) The effects of long-term manipulation of nutrient supply on competition between the seagrass Thalassia tes. tudinum and Halodule wrightii in Florida Bay. Oikos 72 349-358

Fowler N (1986) The role of competition in plant communities in arid and semiarid regions. Annu Rev Ecol Syst 17:89-110

Gerloff GC, Krombholz PH (1966) Tissue analysis as a measure of nutrient availability for the growth of angiosperm aquatic plants. Limnol Oceanogr 11:529-537

Gibson DJ (1988) The maintenance of plant and soil heterogeneity in dune grassland. J Ecol 76:497-508

Goldberg DE, Barton AM (1992) Patterns and consequences of interspecific competition in natural communities: a review of field experiments with plants. Am Nat 139: $771-801$

Grace JB (1991) A clarification of the debate between Grime and Tilman. Funct Ecol 5:583-587

Greig-Smith P (1979) Pattern in vegetation. J Ecol 67:755-779

Grice AM, Loneragan NR, Dennison WC (1996) Light intensity and the interactions between physiology, morphology and stable isotope ratios in five species of seagrass. J Exp Mar Biol Ecol 195:91-110

Harper JL (1977) Population biology of plants. Academic Press, London

Hemminga MA, Harrison PG, Van Lent F (1991) The balance of nutrient losses and gains in seagrass meadows. Mar Ecol Prog Ser 71:85-96

Holt RD (1977) Predation, apparent competition, and the structure of prey communities. Theor Pop Biol 12:197-229

Huisman J (1994) The models of Berendse and Tilman: two different perspectives on plant competition? Funct Ecol 8: $282-288$

Hutchinson GE (1957) Concluding remarks. Cold Spring H.arbor Symp Quant Biol 22:415-427

Iverson RL, Bittaker HF (1986) Seagrass distribution in the eastern Gulf of Mexico. Estuar Coast Shelf Sci 22:577-602

Johnstone I (1984) The ecology and leat dynamics of the seagrass Thalassodendron ciliatum (Forsk.) Den Hartog. Aust J Bot 32:233-238

Kempers AJ, Zweers A (1986) Ammonium determination in soil extracts by the salicylate method. Comm Soil Sci Plant Anal 17:715-723

Kenworthy WJ, Zieman JC, Thayer GW (1982) Evidence for the influence of seagrasses on the benthic nitrogen cycle in a coastal piain estuary near Beaufort, North Carolina (USA). Oecologia 54:152-158

Kira T, Ogawa H, Sakazaki N (1953) Intraspecific competition among higher plants. 1. Competition-yield-density interrelationships in regularly dispersed populations. J I Polytech Osaka D $4: 1-16$

Kirkman $H$ (1985) Community structure in seagrasses in southern western Australia. Aquat Bot 21:363-375

Koyama H, Kira T (1956) Intraspecific competition among higher plant. VIII. Frequency distribution of individual plant weight as affected by individual plants. J I Polytech Osaka D 7:73-94

Lapointe BE, Tomasko DA. Matzie WR (1994) Eutrophication and trophic state classification of seagrass communities in the Florida Keys. Bull Mar Sci 54:696-717

Lemée $R$, Pesando $D$, Durand-Clément $M$, Dubreuil $A$, Meinesz A, Guerriero A. Pietra F (1993) Preliminary survey of toxicity of the green alga Caulerpa taxifolia introduced into the Mediterranean. J Appl Phycol 5:485-493 
McCreary NJ (1991) Competition as a mechanism of submersed macrophyte community structure. Aquat Bot 41: $177-193$

Nadelhoffer KJ, Fry B (1994) Nitrogen isotope studies in forest ecosystems. In: Lajtha K. Michener RH (eds) Stable isotopes in ecology and environmental science. Blackwell Scientific Publications, Oxford, p 22-44

Neckles HA, Wetzel RL, Orth RJ (1993) Relative effects of nutrient enrichment and grazing on epiphyte-macrophyte (Zostera marina L.) dynamics. Oecologia 93 285-295

Neckles HA, Koepfler ET, Haas LW, Wetzel RL, Orth RJ (1994) Dynamics of epiphytic photoautotrophs and heterotrophs in Zostera marina (eelgrass) microcosms: responses to nutrient enrichment and grazing. Estuaries 17 : $597-605$

Nomme KM, Harrison PG (1991) Evidence for interaction between the seagrasses Zostera marina and Zostera japonica on the Pacific coast of Canada. Can J Bot 69: $2004-2010$

Olsen SR, Sommers LE (1982) Phosphorus. In: Black CA (ed) Methods of soil analysis, Part 2. American Society of Agronomy Inc, Madison, WI, p 403-430

Orth RJ, Moore KA (1987) Distribution of Zostera marina L. and Ruppia maritima L. sensu lato along depth gradients in the lower Chesapeake Bay, U.S.A. Aquat Bot 32: 291-305

Patriquin DG (1972) The origin of nitrogen and phosphorus for growth of the marine angiosperm Thalassia testudinum. Mar Biol 15:35-46

Pielou EC (1977) Mathematical ecology. John Wiley \& Sons, New York

Powell GVN, Fourqurean JW, Kenworthy WJ, Zieman JC (1991) Bird colonies cause seagrass enrichment in a subtropical estuary: observational and experimental evidence. Estuar Coast Shelf Sci 32:567-579

Redfield AC (1958) The biological control of chemical factors in the environment. Am Sci 46:205-222

Rejmánek M, Lepš J (1996) Negative associations can reveal interspecific competition and reversal of competitive hierarchies during succession. Oikos 76:161-168

Rose CD (1996) Blade productivity of the seagrass Thalassia testudinum Banks ex König in a heterogeneous community. MS thesis, University of South Florida, Tampa

Sand-Jensen K, Borum J (1991) Interactions among phytoplankton, periphyton, and macrophytes in temperate freshwaters and estuaries. Aquat Bot 41:137-175

Schoener TW (1983) Field experiments on interspecific competition. Am Nat 122:240-285

Short FT (1983) The response of interstitial ammonium in eelgrass (Zostera marina L.) beds to environmental perturbations. J Exp Mar Biol Ecol 68:195-208

Silberstein K, Chiffings AW, McComb AJ (1986) The loss of seagrass in Cockburn Sound, Western Australia. III. The effect of epiphytes on productivity of Posidonia australis hook. F. Aquat Bot 24:355-371

Editorial responsibility: Kenneth L. Heck Jr (Contributing Editor), Dauphin Island, Alabama, USA
Smith SV (1984) Phosphorus versus nitrogen limitation in the marine environment. Limnol Oceanogr 29:1149-1160

South GR (1983) A note on two communities of seagrasses and rhizophytic algae in Bermuda. Bot Mar 26:243-248

Stewart JG (1989) Maintenance of a balanced, shifting boundary between the seagrass Phyllospadix and algal turf. Aquat Bot 33:223-241

Sturgis RB, Murray L (1997) Scaling of nutrient inputs to submersed plant communities: temporal and spatial variations. Mar Ecol Prog Ser 152:89-102

Tilman D (1982) Resource competition and community structure. Princeton University Press, Princeton, NJ

Tilman D (1988) Plant strategies and the dynamics and structure of plant communities. Princeton University Press. Princeton, NJ

Tomasko DA (1992) Variation in growth form of shoal grass (Halodule wrightii) due to changes in the spectral composition of light below a canopy of turtle grass (Thalassia testudinum). Estuaries 15:214-217

Tomasko DA, Lapointe BE (1991) Productivity and biomass of Thalassia testudinum as related to water column nutrient availability and epiphyte levels: field observations and experimental studies. Mar Ecol Prog Ser 75:9-17

Tomasko DA, Dawes CJ, Hall MO (1996) The effects of anthropogenic nutrient enrichment on turtle grass (Thalassia testudinum) in Sarasota Bay, Florida. Estuaries 19:448-456

Turkington R, Klein E, Chanway CP (1993) Interactive effects of nutrients and disturbance: an experimental test of plant strategy theory. Ecology 74:863-878

Turner T (1985) Stability of rocky intertidal surfgrass beds: persistence, preemption, and recovery. Ecology 66:83-92

Tussenbroek BI van (1995) Thalassia testudinum leaf dynamics in a Mexican Caribbean coral reef lagoon. Mar Biol $122: 33-40$

Villèle X de, Verlaque $M$ (1995) Changes and degradation in a Posidonia oceanica bed invaded by the introduced tropical alga Caulerpa taxifolia in the north western Mediterranean. Bot Mar 38:79-87

Williams SL (1987) Competition between the seagrasses Thalassia testudinum and Syringodium filiforme in a Caribbean lagoon. Mar Ecol Prog Ser 35:91-98

Williams SL (1990) Experimental studies of Caribbean seagrass bed development. Ecol Monogr 60:449-469

Wiginton JR, McMillan C (1979) Chlorophyll composition under controlled light conditions as related to the distribution of seagrasses in Texas and the U.S. Virgin Islands. Aquat Bot 6:171-184

Yoda K, Kira T, Ogawa H, Hozumi K (1963) Self-thinning in overcrowded pure stands under cultivated and natural conditions. J Biol Osaka D 14:107-129

Zieman JC (1974) Methods for the study of the growth and production of turtle grass. Thalassia testudinum König Aquaculture 4:139-143

Zieman JC, Fourqurean JW, Iverson RL (1989) Distribution, abundance and productivity of seagrasses and macroalgae in Florida Bay. Bull Mar Sci 44:292-311

Submitted: March 30, 1998; Accepted: February 24, 1999

Proofs received from author(s): July 12, 1999 